\title{
Maternal health training priorities for nursing and allied health workers in Colombia, Honduras, and Nicaragua
}

\author{
Amelia J. Brandt, ${ }^{1}$ Samantha Brown, ${ }^{1}$ Silvia Helena De Bortoli Cassiani, ${ }^{1}$ \\ and Fernando Antonio Menezes da Silva ${ }^{1}$
}

Suggested citation Brandt AJ, Brown S, De Bortoli Cassiani SH, Menezes da Silva FA. Maternal health training priorities for nursing and allied health workers in Colombia, Honduras, and Nicaragua. Rev Panam Salud Publica. 2019;43:e7. https://doi.org/10.26633/RPSP.2019.7

\begin{abstract}
Objective. To assess maternal health training priorities for primary care human resources for health (HRH) in nursing and allied health workers in Colombia, Honduras, and Nicaragua, to inform maternal care HRH strategic planning efforts.

Methods. This Washington, D.C.-based study utilized cross-sectional survey methodology to collect country-level data. From October 2016 to March 2017, a needs assessment tool was developed by the Pan American Health Organization/World Health Organization (PAHO/WHO) and PAHO/WHO Collaborating Centers. Data collection was completed by PAHO/WHO country offices, in collaboration with national health authorities and other high-level government personnel. The collected data included information on the composition, capacities, and training priorities of traditional birth attendants (TBAs), community health workers (CHWs), registered nurses (RNs), and auxiliary nurses in the three study countries; the findings were summarized in a report. Results. Data on the health workforce composition in the three countries indicated reliance on HRH with low levels of education and training, with limited integration of TBAs. In all three countries, management of obstetric emergencies was a training priority for RNs, and identification of danger signs was a priority for $\mathrm{CHWs}$ and TBAs. Training priorities for auxiliary nurses varied widely across the three countries and included health promotion, preconception and prenatal care, and obstetric emergencies. There was also a wide range in the total number of HRH across the three countries.

Conclusions. Reliance on health workers with low levels of training is concerning but can be mitigated through in-service training. Training priorities are consistent with the major causes of maternal mortality, and Latin America and Caribbean region training programs show promise for improving quality of care. In the long term, planning for maternal care HRH should seek to increase the concentration of health professionals that are more highly skilled.
\end{abstract}

Keywords Human resources; maternal health services; primary health care; capacity building; strategic planning; Latin America; Caribbean region; Colombia; Honduras; Nicaragua.

\footnotetext{
Human Resources for Health Unit, Health Systems and Services Department, Pan American Health Organization, Washington, D.C., United States of America. Send correspondence to: Amelia Brandt, brandtame@paho.org
}

Preventable pregnancy- or childbirth-related complications kill 830 women daily, with $99 \%$ of these deaths occurring in developing countries (1).
In addition, for each maternal death, at least 30 women suffer complications with potential long-term consequences (1). 
Maternal mortality (MM) in the Americas region has dropped by more than $40 \%$ in the past 20 years, but these advances do not affect all women equally (2). For example, for 2015, the estimated maternal mortality ratio (MMR) for the Americas is 52 deaths per 100000 live births, but in Latin America and the Caribbean (LAC) it is more than 30\% higher (68) (3). The estimated MMRs of Colombia, Honduras, and Nicaragua are also high at 64 (2014), 129 (2010), and 150 (2016) respectively (3).

The MMR varies by ethnicity, socioeconomic status, and geography $(1,2)$. For example, the 2001 pregnancy-related mortality ratio in Honduras ranged from 177 to 277 across different regions of the country and was higher in those with high poverty and low development (4). The leading direct cause of MM in the Americas is hemorrhage, closely followed by hypertension (5). The estimated proportion of deaths caused by hemorrhage is $23.1 \%$ ( $13.3 \%$ during postpartum, $5.8 \%$ during prepartum, and $4.1 \%$ during intrapartum) (5).

Increased access to skilled birth attendance in low- and middle-income countries has not led to expected reductions in preventable MM and morbidity, possibly due to a lack of good-quality maternity care (6-8). Low-quality services and disrespectful care can harm women's health and well-being (9). Quality must be improved at all levels of care to continue progress in reducing MM and morbidity (10-12). Highly skilled care does not necessarily lead to improved outcomes, even in high-income countries. A review of 13 randomized control trials in Australia, Canada, Ireland, New Zealand, and the United Kingdom found that women who had midwife-led continuity models of care were less likely to experience regional analgesia, episiotomy, and intrapartum analgesia/anesthesia compared to various combinations of care models focused on highly skilled care (13).

Interventions targeting human resources for health (HRH) in the areas of management, education, and policy have been shown to improve HRH capacity and maternal health outcomes (14), especially when there is an emphasis on strengthening primary health care (PHC) $(15,16)$.

The Pan American Health Organization/ World Health Organization (PAHO/WHO) promotes increased access to qualified health workers to achieve sustained and equitable health in the Americas (17). PAHO/WHO Resolution CSP29.R15 (Strategy on Human Resources for Universal Access to Health and Health Coverage), approved in September 2017 at the $29^{\text {th }}$ Pan American Sanitary Conference, reaffirms $\mathrm{PAHO} / \mathrm{WHO}^{\prime}$ s role in providing technical support to member states to improve capacity for strategic HRH planning (18). This type of strategic planning requires the identification of $\mathrm{HRH}$ training priorities in maternal health.

In 2016 and 2017, as part of the IHSLAC project (Integrated Health Systems in Latin America and the Caribbean), funded by Global Affairs Canada, a survey tool was developed to conduct an assessment of maternal health training priorities for nursing and allied health workers working in the first level of care in Colombia, Honduras, and Nicaragua. These three countries were selected for the study based on the accessibility of country information, the MMR, and the level of interest of the $\mathrm{PAHO} / \mathrm{WHO}$ country offices and national health authorities.

The objective of the study was to assess maternal health training priorities for primary care $\mathrm{HRH}$ in nursing and allied health workers in Colombia, Honduras, and Nicaragua, to guide maternal care $\mathrm{HRH}$ strategic planning efforts. The study was designed to contribute to LAC country efforts to achieve universal access to health, universal health coverage, and the Sustainable Development Goals (SDGs). ${ }^{2}$ The assessment was limited to nursing and allied health workers to match the scope of the training efforts that will be informed by the study results.

\section{MATERIALS AND METHODS}

This study used a cross-sectional quantitative survey methodology to collect country-level data on national maternal HRH needs.

The survey instrument was developed by PAHO/WHO's Department of Health Systems and Services/Human Resources for Health Unit (HSS/HR) in collaboration with the following $\mathrm{PAHO} / \mathrm{WHO}$ Collaborating Centers: University of Chile, University of Miami, University of Michigan, University of Pennsylvania, and University of São

2 This assessment focused on SDG Goals 3, 5, 10, and 17. More details on the SDGs can be found at: http://www.un.org/sustainabledevelopment
Paulo. The development of the instrument was informed by a literature review on maternal health in the Americas region and existing tools $(19,20)$.

The Spanish-language instrument consisted of a 24-page written survey divided into three sections (health care personnel, training needs, and country resources). The target population included four categories of health workers providing maternal health care at the primary care level in LAC countries: traditional birth attendants (TBAs), community health workers (CHWs), registered nurses (RNs), and auxiliary nurses. These categories were selected based on consultations with maternal health experts and country offices on the key nursing and allied health workers providing maternal health services in the three countries studied. The four groups were defined as follows using internationally recognized criteria: 1) TBA-person without formal education who assists mothers through childbirth using skills learned through delivering babies herself or through an apprenticeship with other TBAs; 2) CHW—community member selected by peers who works in the community to provide care to support health care delivery and has no formal professional certificate or degree; 3) RN-individual who has graduated from a nursing program typically lasting three to four years and has legal authority to practice as a nurse in his/her country based on national regulations and licensing; and 4) auxiliary nurse-individual with basic nursing knowledge and, usually, high school-level training, who may have some on-the-job training but has no training in nursing decision-making.

The health care personnel section of the survey instrument covered in this report was designed to collect information on the general characteristics and scopes of practice for each type of health worker. The three country-level survey respondents were asked to answer circle-response questions and describe, in writing, key capacities for each type of provider and the scope of their practice in the country. Both multiple-choice and open-ended questions were used to elicit general descriptions related to the number, geographic distribution, education requirements, community standing, number of births attended, regulation, payment, training, access to higher levels of care, and barriers of 
each group of health worker. To identify scopes of practice, the instrument provided lists of skill sets for each group and prompted respondents to select all that were applicable and rank the three most important. The question on ranking was open-ended. Figure 1 shows a summary of the information collected for this part of the survey. The other two sections of the survey (training needs and country resources) were not used in this assessment, as it was designed to gather data on HRH training, so are not described here in detail. The survey instrument can be made available on request to the corresponding author (AJB).

Data collection was completed between October 2016 and March 2017 by the $\mathrm{PAHO} / \mathrm{WHO}$ country offices in the three countries studied in collaboration with national health authorities. One survey was completed for each country. The collaborating government personnel were selected by the PAHO/WHO country offices.

Upon receipt of the completed surveys, the research team reviewed and analyzed the data and summarized the findings in a report. The terminology used to identify health priorities was standardized to allow for comparison across countries. The original and standardized terminology are available from the corresponding author (AJB) upon request. The summary report was shared with each PAHO/WHO country office for review and feedback.

\section{Ethics approval}

The study protocol was submitted to the PAHO Ethics Review Committee, which determined it exempt from review as it was not human subjects research.

FIGURE 1. Summary of information collected in the personnel section of the Pan American Health Organization (PAHO)/World Health Organization (WHO) human resources for health (HRH) needs assessment survey

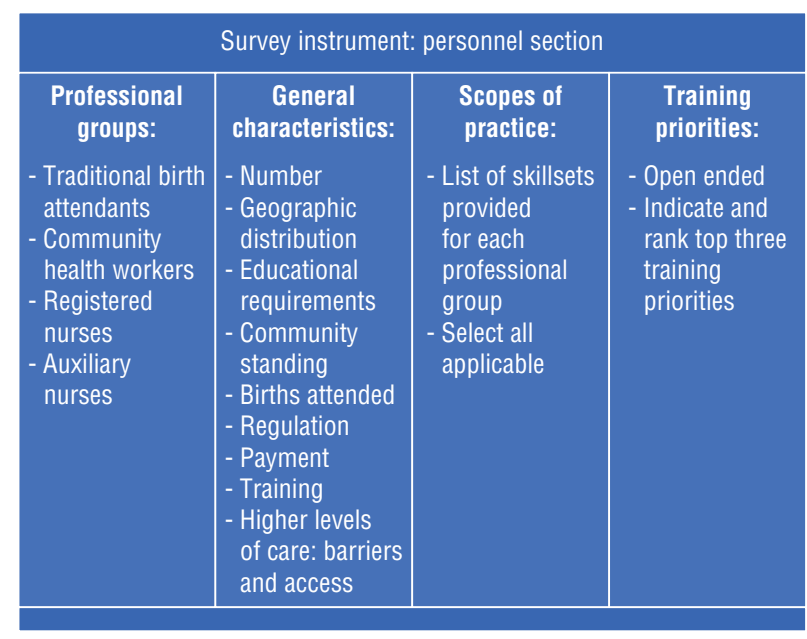

Source: PAHO/WHO HRH needs assessment survey.

TABLE 1. Human resources for health (HRH) in nursing and allied personnel, based on the results of a country-level Pan American Health Organization/World Health Organization needs assessment survey, Colombia, Honduras, and Nicaragua, 2017

\begin{tabular}{|c|c|c|c|c|c|c|}
\hline \multirow{2}{*}{$\mathrm{HRH}$} & \multicolumn{2}{|c|}{ Colombia } & \multicolumn{2}{|c|}{ Honduras } & \multicolumn{2}{|c|}{ Nicaragua } \\
\hline & No. & $\%$ & No. & $\%$ & No. & $\%$ \\
\hline Registered nurses (RNs) & 55256 & 18.6 & 2088 & 29.4 & 4448 & 6.2 \\
\hline Auxiliary nurses & 241621 & $81.4^{\mathrm{a}}$ & 5000 & 70.6 & 3886 & $5.4^{\mathrm{b}}$ \\
\hline Community health workers (CHWs) & \multicolumn{2}{|c|}{$N D^{C}$} & \multicolumn{2}{|c|}{ ND } & 57346 & 79.5 \\
\hline Traditional birth attendants (TBAs) & - & $<1.0^{\mathrm{d}}$ & \multicolumn{2}{|c|}{ ND } & 6432 & 8.9 \\
\hline Total & 296877 & & 7088 & & 72112 & \\
\hline
\end{tabular}

Source: Prepared by the authors based on the survey results.

a Includes auxiliary nurses and medical technicians.

${ }^{b}$ Includes only those working in the public sector.

${ }^{c} \mathrm{ND}$ : no data provided.

anofficial estimate.

\section{RESULTS}

\section{Workforce composition}

The total number of CHWs, RNS, and TBAs in the nursing and allied health personnel workforce varied considerably across the three countries studied, ranging from almost 300000 in Colombia, to 72112 in Nicaragua, to 7088 in Honduras (Table 1).

There was also a wide range in the workforce composition across countries. For example, auxiliary nurses comprised the majority of the workforce in Colombia and Honduras but only $5.4 \%$ in Nicaragua. While CHWs made up the majority of Nicaragua's workforce, no data were provided on this group by respondents from Colombia or Honduras. Honduras had the highest percentage of RNs, followed by Colombia. In contrast, RNs made up only $6.2 \%$ of Nicaragua's workforce.

TBAs were not integrated into the formal health system in Honduras or Colombia. Therefore, the respondents from Honduras did not provide any data for this group and those from Colombia provided only an unofficial estimate. In Nicaragua, TBAs made up $8.9 \%$ of the workforce, outnumbering auxiliary nurses and RNs.

\section{Capacity requirements}

Key capacities required for RNs in maternal health were similar in Colombia, Honduras, and Nicaragua and included preconception, prenatal, and intrapartum care; delivery of uncomplicated pregnancy; management of preeclampsia and eclampsia; management of postpartum bleeding and hemorrhage; recognition of symptoms of premature labor; management of premature labor; suture of episiotomies; administration of blood transfusions; postpartum care; newborn care; family planning services; breastfeeding education; identification of complications and timely referrals; medication administration; contraceptive counseling; assistance with spontaneous abortion; referral of complicated abortions; care for postpartum depression; and HIV/ AIDS care. Manual removal of the placenta was indicated as a necessary capacity for nursing practice in Colombia and Nicaragua, but not Honduras. 
TABLE 2. Key capacities for auxiliary nurses, based on the results of a country-level Pan American Health Organization/World Health Organization needs assessment survey on human resources for health (HRH), Colombia, Honduras, and Nicaragua, 2017

\begin{tabular}{lccc}
\hline Key capacity & Colombia & Honduras & Nicaragua \\
\hline Preventive care against HIV, malaria, tetanus, STIs, etc. & $\mathrm{x}$ & $\mathrm{x}$ & $\mathrm{x}$ \\
Health promotion & $\mathrm{x}$ & $\mathrm{x}$ & $\mathrm{x}$ \\
Breastfeeding education and evaluation & $\mathrm{x}$ & $\mathrm{x}$ & $\mathrm{x}$ \\
Neonatal care & $\mathrm{x}$ & $\mathrm{x}$ & $\mathrm{x}$ \\
Prenatal care & $\mathrm{x}$ & $\mathrm{x}$ & $\mathrm{x}$ \\
Intrapartum care & $\mathrm{x}$ & & $\mathrm{x}$ \\
Delivery of uncomplicated pregnancy & $\mathrm{x}$ & $\mathrm{x}$ & $\mathrm{x}$ \\
Recognizing signs and symptoms of major complications during pregnancy & $\mathrm{x}$ & $\mathrm{x}$ & $\mathrm{x}$ \\
Family planning services & $\mathrm{x}^{\mathrm{a}}$ & $\mathrm{x}$ & $\mathrm{x}$ \\
Administering medication & & $\mathrm{x}$ & $\mathrm{x}$ \\
Fetal monitoring & & $\mathrm{x}$ & $\mathrm{x}$ \\
Bimanual massage & & $\mathrm{x}^{\mathrm{b}}$ & $\mathrm{x}$ \\
\hline
\end{tabular}

Source: Prepared by the authors based on the survey results.

${ }^{\mathrm{a}}$ Accompaniment and counseling only.

${ }^{b}$ Prior to birth.

TABLE 3. Key capacities for community health workers (CHWs) and traditional birth attendants (TBAs), based on the results of a country-level Pan American Health Organization/World Health Organization needs assessment survey on human resources for health (HRH), Colombia, Honduras, and Nicaragua, 2017

\begin{tabular}{|c|c|c|c|c|c|}
\hline \multirow{2}{*}{ Key capacity } & \multicolumn{3}{|c|}{ CHWs } & \multicolumn{2}{|c|}{ TBAs } \\
\hline & Colombia & Honduras & Nicaragua & Colombia & Nicaragua \\
\hline $\begin{array}{l}\text { Preventive care against HIV, malaria, tetanus, } \\
\text { STIs, etc. }\end{array}$ & $\mathrm{x}$ & $\mathrm{x}$ & $\mathrm{x}$ & & \\
\hline Health promotion & $x$ & $x$ & $x$ & & \\
\hline Breastfeeding education and evaluation & & $x$ & $x$ & $x$ & $x$ \\
\hline Neonatal care & & & $x$ & $x$ & $x^{a}$ \\
\hline Prenatal care & & & & $x$ & \\
\hline Intrapartum care & & & & $x$ & \\
\hline Delivery of uncomplicated pregnancy & & & & $x$ & $x$ \\
\hline $\begin{array}{l}\text { Recognizing signs and symptoms of } \\
\text { major complications during pregnancy }\end{array}$ & $x$ & $x$ & $x$ & $x$ & $x$ \\
\hline Family planning services & & $x$ & & $x^{b}$ & $x^{b}$ \\
\hline Administering medication & & & & & \\
\hline $\begin{array}{l}\text { Fetal monitoring } \\
\text { Bimanual massage }\end{array}$ & & & & & \\
\hline
\end{tabular}

Source: Prepared by the authors based on the survey results.

a In the home.

${ }^{\mathrm{b}}$ Accompaniment and counseling only.

In all three countries, auxiliary nurses had considerably less education and training than RNs, and their scope of practice was more limited. Key capacities for auxiliary nurses by country are shown in Table 2.

Another characteristic common to all three countries was that auxiliary nurses and RNs had similar key capacities, including breastfeeding education, prenatal and neonatal care, family planning services, and delivery of uncomplicated pregnancy. However, other capacities were exclusive to one of the four groups of health workers. For example, key responsibilities indicated for RNs but not auxiliary nurses included preeclampsia and eclampsia, postpartum bleeding and hemorrhage, premature labor, suturing episiotomies, blood transfusions, spontaneous abortion, HIV/AIDS, and postpartum depression. Key responsibilities indicated for auxiliary nurses but not RNs tended to focus on preventive and administrative care such as infection prevention, health promotion, and recognition of signs and symptoms of major complications during pregnancy.
With some exceptions, capacities for auxiliary nurses were relatively consistent across all three countries. Honduras was unique in that intrapartum care was not a necessary capacity for auxiliary nurses. Administering medication, fetal monitoring, and bimanual massage were indicated as necessary capacities in Honduras and Nicaragua, but not Colombia.

CHWs and TBAs, who work primarily in the community, generally had limited or no formal education and therefore a limited scope of work. Table 3 lists key CHW and TBA capacities by country.

Colombia required only three capacities for CHWs: 1) health promotion, 2) recognizing signs and symptoms of complications during pregnancy, and 3) preventive care against infections. Both Honduras and Nicaragua required CHWs to have those capacities in addition to others, including the ability to provide breastfeeding education and evaluation. In Honduras, CHWs were also required to have the capacity to provide family planning services and sexual education. In Nicaragua, CHWs were also required to have the capacity to provide neonatal care; identify danger signs during pregnancy, birth, postpartum, and childhood; and carry out chronic and febrile illnesses prevention activities.

In both Colombia and Nicaragua, required capacities for TBAs included breastfeeding education and evaluation, delivery of uncomplicated pregnancy, accompaniment and counseling for family planning services, and recognition of signs and symptoms of major complications during pregnancy. Bimanual massage was only a required capacity in Nicaragua. In Nicaragua and Colombia, TBAs also needed to have multiple key capacities directly related to clinical care, despite education limitations. For example, neonatal care and delivery of uncomplicated pregnancy were identified as necessary capacities for TBAs in both countries. In Nicaragua, neonatal care delivered by TBAs had to take place in the home. Colombia identified prenatal and intrapartum care as necessary capacities for TBAs. Nicaragua highlighted the transport of children and mothers to health facilities as a responsibility of TBAs, who were described as authorities in maternal and child health issues in some indigenous communities. 
Though both CHWs and TBAs work directly in the community, they shared ty indicated for both categories in all three countries was recognition of signs and symptoms of major complications during pregnancy. In Nicaragua, TBAs and CHWs shared additional capacities, including breastfeeding evaluation/education and neonatal care. Capacities indicated for CHWs but not TBAs in all three countries included health promotion and prevention of infectious diseases.

Recognizing signs and symptoms of major complications during pregnancy was identified as vital for all groups of health workers in all three countries. Another characteristic common to all three countries was requiring provision of family planning services as a key capacity for auxiliary nurses and RNs. In Honduras, this capacity was a required key capacity for all four health worker groups. Breastfeeding education and evaluation was another key capacity for all four groups of health workers in Nicaragua and Honduras.

\section{Training priorities}

In addition to identifying the capacities/scope of work for each of the four groups of health workers in their few key capacities. The only key capaci-

country, survey respondents identified the three highest priorities for further training for each. Honduras did not identify training priorities for TBAs. Table 4 presents training priorities by country and health worker group, with " 1 " indicating the highest priority.

Training priorities for RNs varied across the three countries but there were some similarities. For example, management of obstetric emergencies was included as either a first or second priority for all countries. Some training priorities listed by respondents were similar across countries but with a slight variation, such as identification of danger signs in Colombia, and referral and counterreferral following identification of danger signs in Nicaragua. Each country also had some unique priorities, such as preconception and prenatal care in Colombia; management of preeclampsia and eclampsia in Honduras; and nursing standards in Nicaragua.

Training priorities for auxiliary nurses varied widely across the three countries, with no priority being listed by more than one country. The priorities identified by Nicaragua and Honduras indicated a more active role for this group in pregnancies, as illustrated by the inclusion of delivery of uncomplicated pregnancy in Honduras and management of obstetric emergencies in Nicaragua.

TABLE 4. Top three training priorities for registered nurses (RNs), auxiliary nurses, community health workers (CHWs), and traditional birth attendants (TBAs), based on a country-level Pan American Health Organization/World Health Organization needs assessment survey on human resources for health, Colombia, Honduras, and Nicaragua, 2017

\begin{tabular}{|c|c|c|c|c|c|c|c|c|c|c|c|}
\hline \multirow{3}{*}{ Training area } & \multicolumn{3}{|c|}{ RNs } & \multicolumn{3}{|c|}{ Auxiliary nurses } & \multicolumn{3}{|c|}{ CHWs } & \multicolumn{2}{|c|}{ TBAs } \\
\hline & 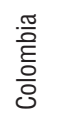 & 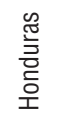 & 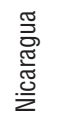 & $\begin{array}{l}\frac{. \pi}{0} \\
\frac{E}{0} \\
\frac{0}{0}\end{array}$ & 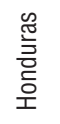 & 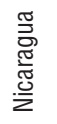 & $\begin{array}{l}\frac{. \pi}{0} \\
\frac{1}{E} \\
\text { 응 }\end{array}$ & 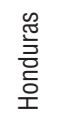 & 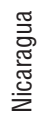 & $\begin{array}{l}\frac{\pi}{0} \\
\frac{E}{E} \\
\text { 응 }\end{array}$ & 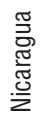 \\
\hline & \multicolumn{11}{|c|}{ Priority level } \\
\hline Breastfeeding education and evaluation & & & & 2 & & & & & & 3 & \\
\hline Care and knowledge of newborn danger signs & & & & & & & & & & & 3 \\
\hline Delivery of uncomplicated pregnancy & & 3 & & & 3 & & & & & 2 & \\
\hline Family planning services & & & & & 2 & & & 2 & & & \\
\hline Health promotion & & & & 1 & & & 1 & & & & \\
\hline Identification of danger signs & 3 & & & 3 & & & 2 & 1 & 1 & 1 & 2 \\
\hline Managing preeclampsia and eclampsia & & 1 & & & & & & & & & \\
\hline Nursing standards & & & 3 & & & & & & & & \\
\hline Obstetric emergencies & 1 & 2 & 2 & & & 1 & & & & & \\
\hline Preconception and prenatal care & 2 & & & & 1 & & & & & & \\
\hline Prevention of infections and chronic diseases & & & & & & 3 & 3 & 3 & 3 & & \\
\hline Referral and counter-referral & & & 1 & & & 2 & & & 2 & & 1 \\
\hline
\end{tabular}

Source: Prepared by the authors based on the survey results.
In contrast, Colombia's priorities reflected an emphasis on prevention.

CHW training priorities were similar across all three countries. Identifying danger signs was the highest priority for Honduras and Nicaragua and second priority for Colombia. Nicaragua also mentioned the Three Delays Model $^{3}$ (21) with regard to this priority. Preventive care was the third priority for all three countries. In Colombia and Honduras, the focus was HIV, malaria, tetanus, and STIs, while in Nicaragua it was chronic diseases. The remaining priorities varied by country.

Training priorities for TBAs in Colombia and Nicaragua were varied. Both countries prioritized training on identification of danger signs, but Colombia limited this to pregnancy, while Nicaragua included identification of these signs during birth and postpartum, and for newborns. Other priorities were unique to each country's context. In Honduras, delivery of uncomplicated pregnancy was listed as a priority for auxiliary nurses and RNs. In Colombia, breastfeeding education/evaluation was prioritized for auxiliary nurses and TBAs.

\section{DISCUSSION}

Although the global community has made significant strides in reducing MM, much progress remains to be made (1). While the estimated MMR for the Americas for 2015 (52) was below the SDG target (70 deaths per 100000 live births), it remained unacceptably high $(3,22)$. In 2017, ministers and secretaries of health in the region unanimously endorsed the Sustainable Health Agenda for 20172030, which established a goal for reducing the MMR for the Americas to less than 30 (23).

Country case studies have shown that integrating PHC strategies into maternal, newborn, and child health $(\mathrm{MNCH})$ programs has the potential to reduce maternal deaths by $20 \%-30 \%$ and strengthening $\mathrm{MNCH}$ programs at the primary level is recommended to reduce MM (14). PHC requires a well-trained health workforce to reduce MM, and strategic planning is vital to developing appropriate and effective training. The results of this study can be used to inform strategic planning for training $\mathrm{HRH}$ at both the national level and for the Americas region.

3 The idea that MM is related to delays in 1) deciding to seek care; 2 ) reaching the health care facility; and 3 ) receiving care. 


\section{Workforce composition}

Appropriate planning for training requires a clear understanding of $\mathrm{HRH}$ composition, especially for in-service programs (24). The lack of data in this area indicates the need to improve $\mathrm{HRH}$ monitoring for nursing and allied health workers. For example, in this assessment, the number of CHWs in Honduras and Colombia could not be determined. In addition, a large percentage of the nursing and allied health workforce in the three sample countries included health workers with limited or no formal health education, such as auxiliary nurses, CHWs, and TBAs. While this limits HRH capacity, in-service training can be an effective tool for improving the skills of these three groups of health workers $(25,26)$. In line with PAHO's Strategy on Human Resources for Universal Access to Health and Universal Health Coverage (18), national health authorities, universities, and professional associations should play a significant role in the provision of ongoing training and professional development opportunities, as well as regular assessment of the training needs of nursing and allied health workers, through studies similar to the one reported here.

Training efforts designed for the Americas region as a whole contribute to the streamlining of the development of $\mathrm{MNCH}$ training materials and facilitate resource- and knowledge-sharing across countries (27). However, it is important to consider the consistency of health worker roles across countries and to take country contexts and training priorities into account, given the findings reported here, which highlight variation in the key capacities of these health workers across countries.

\section{Capacity requirements}

Capacity requirements for RNs were remarkably consistent for Colombia, Honduras, and Nicaragua. This is promising as it may indicate coordination across LAC in the development of the profession. Auxiliary nurses also have a similar role in each of the three countries, although there was more variation compared to RNs. The role of auxiliary nurses in Colombia was more limited than in Nicaragua or Honduras, even though, in all three countries, this group comprised most of the nursing and allied health personnel workforce. The results of this study highlight the discrepancies between the capacity of auxiliary nurses and their scope of work, likely due to resource shortages. Although increased training of auxiliary nurses can improve the provision of basic preventive or primary care services (28), HRH planning must address the need for equitable access to highly skilled personnel $(18,29,30)$.

At the community level, for all countries studied, CHWs were a more integral part of the workforce than TBAs. The only country of the three where TBAs had a formalized role was Nicaragua, and even there, they comprised a smaller part of the workforce than CHWs. Although Colombia and Honduras did not provide data on CHWs, it seems likely that both countries have a large CHW workforce, given the large number of CHWs in Nicaragua. In addition, both Colombia and Honduras provided information about $\mathrm{CHW}$ scope of practice and training priorities, indicating that although numerical data were missing for this assessment, CHWs are considered part of the workforce.

\section{Training priorities}

Despite HRH similarities in all three countries, there was significant variation in training priorities. While priority-setting is complex and multifaceted, some hypotheses can be developed. For example, Colombia was the only country that identified breastfeeding education as a priority, and it had higher exclusive breastfeeding rates than the other two countries, possibly indicating a focus on this area (3). Similarly, Nicaragua, the only country identifying care and knowledge of newborn danger signs as a priority, had lower neonatal mortality than Honduras (3). Nicaragua was also the only country that identified obstetric emergencies as a priority for auxiliary nurses, which seems logical, as it has the widest scope of work for this group of professionals of all three countries. Family planning services were identified as a priority in Honduras only, which may be due to its low use of modern contraception and high unmet need compared to Colombia and Nicaragua (3).

Training priority variation for nurses could be addressed by developing training materials for each identified area and allowing countries to select and adapt the materials. However, for some of the nursing and allied health workers, such as auxiliary nurses, the priorities were so varied that consensus-building would be required to carry out training across LAC. In contrast, training priorities were relatively consistent across the three countries for CHWs. Given that Nicaragua was the only country where TBAs had a formalized role, a regional training approach would not be appropriate.

When planning training based on national interests, the national training priorities for various categories of health workers emerging within countries should be considered. For the three countries and four groups of health workers assessed in this study, these would include referral and counter-referral in Nicaragua, recognition of complications during pregnancy and breastfeeding education in Colombia, and delivery of uncomplicated pregnancy in Honduras.

Training should also focus on hemorrhage and hypertension, the two leading causes of MM in the LAC region (5). Based on the survey results, in all three countries studied, identification of danger signs was a top training priority for at least one of the four categories of health worker, and obstetric emergencies was a priority for RNs. These findings are promising with regard to maternal health progress, as improving these two capacities alone could significantly reduce maternal deaths due to hemorrhage and hypertension $(31,32)$. However, prenatal care was only indicated as a training priority for auxiliary nurses in Honduras, and for RNs in Colombia. Complete prenatal care significantly reduces mortality in pregnant women with hypertensive disorders (33), so its emphasis in training would likely contribute to reduction of $\mathrm{MM}$ at the primary care level. Task shifting is also a key strategy to improve access to health care. WHO recognizes task shifting as an important tool to increase accessibility of basic health services in low-resource settings $(34,35)$. This supports increased investment in training of nondoctor personnel who are influential in the realm of maternal health, including CHWs, auxiliary nurses, RNs, and TBAs.

\section{Limitations}

This study had some limitations. First, much of the health workforce composition data were missing or estimated. 
Other limitations included the use of open-ended questions in the survey section on training priorities, to allow for flexibility in responses, which required conversion to standardized terminology to allow for inter-country analysis.

\section{Conclusions}

The importance of $\mathrm{HRH}$ at the primary level for improving maternal health is well-established. However, low-quality services impede and may jeopardize maternal health progress. HRH training can increase the quality of existing services and improve maternal health across the LAC region. The current nursing and allied health personnel workforce in Colombia, Honduras, and Nicaragua is composed primarily of lower-educated health workers. To build capacity, it is important to strategically plan to increase the number of more highly

educated professionals. However, it is also essential to provide high-quality in-service education to the existing workforce, in order to meet immediate needs, and to continue to assess capacities and training needs.

Strategic planning is vital to ensure national and regional training programs meet training needs and have high impact. This assessment provides key information for planning training to build HRH capacity for maternal health in Colombia, Honduras, Nicaragua, and in the $\mathrm{LAC}$ region overall. The results from the study are currently being used by $\mathrm{PAHO} / \mathrm{WHO}$ and national health authorities to develop training for national trainers in maternal health.

Acknowledgments. The authors would like to acknowledge the contributions of colleagues at the PAHO/ WHO offices in Colombia, Honduras, and Nicaragua as well as the Ministries of Health of these countries in completing the needs assessment tool and assisting in the interpretation of results. They also thank the PAHO/WHO Collaborating Centers (University of Chile, University of Miami, University of Michigan, University of Pennsylvania, and University of São Paulo) for their contributions in preparing the needs assessment tool.

Funding. This research was funded by Global Affairs Canada through the Integrated Health Systems in Latin America and the Caribbean grant.

\section{Conflicts of interest. None.}

Disclaimer. Authors hold sole responsibility for the views expressed in the manuscript, which may not necessarily reflect the opinion or policy of the RPSP / PAJPH or the Pan American Health Organization (PAHO).

\section{REFERENCES}

1. Alkema L, Chou D, Hogan D, Zhang S, Moller AB, Gemmill A, et al. Global, regional, and national levels and trends in maternal mortality between 1990 and 2015, with scenario-based projections to 2030: a systematic analysis by the UN Maternal Mortality Estimation Inter-Agency Group. Lancet. 2016;387(10017):462-74.

2. World Bank. Latin America: unequal access to health care is still no. 1 killer for moms and kids [news release]. 11 Sept 2013. Washington: World Bank; 2013. Available from: http://www.worldbank. org / en/news / feature/2013/09/11/ mother-child-healthcare-inequalities-latin-america

3. Pan American Health Organization. Health situation in the Americas: core indicators. Washington: PAHO; 2017. Available from: http://iris.paho.org/xmlui/bitstream/handle/123456789/34329/ CoreIndicators2017_eng.pdf?sequence $=$ 1 \&isAllowed $=\mathrm{y} \& u a=1$

4. Queiroz BL. Estimating maternal mortality differentials using census data: experience in Honduras. J Popul Res. 2011;28(1):75-87.

5. Say L, Chou D, Gemmill A, Tunçalp Ö, Moller AB, Daniels J, et al. Global causes of maternal death: a WHO systematic analysis. Lancet Glob Health. 2014;2(6): e323-33.

6. United Nations Population Fund. The state of the world's midwifery 2011: delivering health, saving lives. New York: UN; 2011. Available from: https://www.unfpa. org/sites/default/files/pub-pdf/en_ SOWMR_Full.pdf

7. Tunçalp Ö, Were WM, MacLennan C, Oladapo OT, Gülmezoglu AM, Bahl R, et al. Quality of care for pregnant women and newborns-the WHO vision. BJOG. 2015;122(8):1045-9.

8. Horton R, Astudillo O. The power of midwifery. Lancet. 2014;384(9948):1075-6.

9. Graham WJ, McCaw-Binns A, Munjanja S. Translating coverage gains into health gains for all women and children: the quality care opportunity. PLoS Med. 2013;10(1):e1001368.

10. World Health Organization. The world health report 2005: make every mother and child count. Geneva: WHO; 2005. Available from: http://www.who.int/ whr/2005/whr2005_en.pdf?ua=1

11. Souza JP, Gülmezoglu AM, Vogel J, Carroli G, Lumbiganon P, Qureshi Z, et al. Moving beyond essential interventions for reduction of maternal mortality (WHO Multicountry Survey on Maternal and Newborn Health): a cross-sectional study. Lancet. 2013;381(9879):1747-55.

12. Graham WJ, Varghese B. Quality, quality, quality: gaps in the continuum of care. Lancet. 2012;379(9811):e5-6.

13. Sandall J, Soltani H, Gates S, Shennan A, Devane D. Midwife-led continuity models versus other models of care for childbearing women. Cochrane Database Syst Rev. 2016;4:CD004667.

14. Bhutta ZA, Lassi ZS, Mansoor N. Systematic review on human resources for health interventions to improve maternal health outcomes: evidence from developing countries. Geneva: World Health Organization; 2010. Available from: http://www.who.int/pmnch/activities / human_resources/hrh_maternal_ health_2010.pdf

15. Bhutta ZA, Ali S, Cousens S, Ali TM, Haider BA, Rizvi A, et al. Alma-Ata: rebirth and Revision 6 Interventions to address maternal, newborn, and child survival: what difference can integrated primary health care strategies make? Lancet. 2008;372(9642):972-89.

16. Jennings MC, Pradhan S, Schleiff M, Sacks E, Freeman PA, Gupta S, et al. Comprehensive review of the evidence regarding the effectiveness of communitybased primary health care in improving maternal, neonatal and child health: 2 . maternal health findings. J Glob Health. 2017;7(1):010902.

17. Pan American Health Organization Resolution CD12.R13: Human resources for health: increasing access to qualified health workers in primary health carebased health systems. Presented at the $52^{\text {nd }}$ Directing Council, Sept 30-Oct 4 2013, Washington, D.C. Washington: PAHO; 2013. Available from: http://iris.paho. org/xmlui/handle/123456789/4441

18. Pan American Health Organization. Resolution CSP29.R15: Strategy on Human Resources for Universal Access to Health and Universal Health Coverage. Presented at the $29^{\text {th }}$ Pan American Sanitary Conference, 25-29 September 2017, Washington, D.C. Washington: PAHO; 2017. Available from: https:// www.paho.org/hq/index.php?option=com_docman\&task=doc_download \&gid $=42333 \&$ Itemid $=270$ \&lang $=$ en

19. Hicks C, Hennessy D. Hennessy-Hicks training needs analysis questionnaire and manual. Birmingham (UK); University of Birmingham [licensed to WHO for online use]. 2011. Available from: http://www. who.int/workforcealliance/knowledge/ HennessyHicks_trainingneedstool.pdf 
20. World Health Organization. Assessment of human resources for health: survey instruments and guide to administration. Geneva: WHO; 2002. Available from: http://www.who.int/hrh/tools/hrh_assessment_guide.pdf?ua $=1$

21. Thaddeus S, Maine D. Too far to walk: maternal mortality in context. Soc Sci Med. 1994;38(8):1091-110.

22. United Nations. Sustainable Development Goals: Goal 3 [Internet]. New York: UN; 2015. Available from: http://www.un.org/sustainabledevelopment/health Accessed on 26 June 2018.

23. Pan American Health Organization. Sustainable health agenda for the Americas 2018-2030: a call to action for health and well-being in the region. Presented at the 160th Session of the Executive Committee, 26-30 June 2017, Washington, D.C. Washington: PAHO; 2017. Available from: https://www.paho.org/hq/index.php?option=com_docman\&task=doc_download\& gid $=40341 \&$ Itemid $=270 \&$ lang $=$ en

24. World Health Organization. Handbook on monitoring and evaluation of human resources for health. Geneva: WHO; 2009. Available from: http://apps.who.int/ iris/bitstream/handle/10665/44097/978 9241547703_eng.pdf; jsession id=E5A372EA129848DCF95523D3C032C BB0?sequence $=1$

25. Sibley LM, Sipe TA. Transition to skilled birth attendance: is there a future role for trained traditional birth attendants? J Health Popul Nutr. 2006;24(4):472-8.

26. Nelson BD, Ahn R, Fehling M, Eckardt MJ, Conn KL, El-Bashir A, et al. Evaluation of a novel training package among frontline maternal, newborn, and child health workers in South Sudan. Int J Gynaecol Obstet. 2012;119(2):130-5.

27. Cassiani SHB, Wilson LL, Mikael SSE, Peña LM, Grajales RAZ, McCreary LL, et al. The situation of nursing education in Latin America and the Caribbean towards universal health. Rev Lat Am Enfermagem. 2017;25:2913.

28. World Health Organization. Using auxiliary nurse midwives to improve access to key maternal and newborn health interventions. Geneva: WHO; 2014 Available from: http://www.who.int/ reproductivehealth / publications / maternal_perinatal_health/rhr1422/en

29. de Bernis L, Sherratt DR, AbouZahr C, Van Lerberghe W. Skilled attendants for pregnancy, childbirth and postnatal care. Br Med Bull. 2003;67(1):39-57.

30. Pan American Health Organization. Expanding the roles of nurses in primary health care. Washington: PAHO; 2018. Available from: http://iris.paho.org/xmlui/handle/123456789/34958

31. Mhyre JM, D'Oria R, Hameed $A B$, Lappen JR, Holley SL, Hunter SK, et al. The maternal early warning criteria: a proposal from the national partnership for maternal safety. J Obstet Gynecol Neonatal Nurs. 2014;43(6):771-9.

32. Dumont A, Gaye A, Mahé P, BouvierColle MH. Emergency obstetric care in developing countries: impact of guidelines implementation in a community hospital in Senegal. BJOG. 2005;112(9): 1264-9.

33. Barbosa IR, Silva WB, Cerqueira GS, Novo NF, Almeida FA, Novo JL. Maternal and fetal outcome in women with hypertensive disorders of pregnancy: the impact of prenatal care. Ther Adv Cardiovasc Dis. 2015;9(4):140-6.

34. World Health Organization. WHO recommendations: optimizing health worker roles to improve access to key maternal and newborn health interventions through task shifting. Geneva: WHO; 2012. Available from: http://www.who.int/ iris/handle/10665/77764

35. Floyd BO, Brunk N. Utilizing task shifting to increase access to maternal and infant health interventions: a case study of midwives for Haiti. J Midwifery Womens Health. 2016;61(1):103-11.

Manuscript submitted 8 May 2018. Revised version accepted for publication on 11 July 2018. 
RESUMEN

\section{Prioridades de capacitación en el ámbito de la salud materna para el personal de enfermería y otros trabajadores de salud en Colombia, Honduras y Nicaragua}

\author{
Palabras clave
}

Objetivo. Evaluar las prioridades de capacitación en el ámbito de la salud materna de los recursos humanos de enfermería y otros trabajadores de atención primaria en Colombia, Honduras y Nicaragua, y fundamentar los esfuerzos de planificación estratégica de los recursos humanos para la salud dedicados a la atención materna.

Métodos. En este estudio, con sede en Washington, D. C., se empleó una metodología de encuesta transversal para recopilar datos a nivel de país. Entre los meses de octubre del 2016 y marzo del 2017, la Organización Panamericana de la Salud/Organización Mundial de la Salud (OPS/OMS) y sus centros colaboradores elaboraron una herramienta para la evaluación de las necesidades. Las representaciones de la OPS/OMS, en colaboración con las autoridades nacionales de salud y otros funcionarios gubernamentales de alto nivel, realizaron la recopilación de datos. Los datos reunidos incluyeron información sobre la composición, las aptitudes y las prioridades de capacitación de las parteras tradicionales, los agentes comunitarios de salud, las enfermeras tituladas y las enfermeras auxiliares en los tres países del estudio. Los resultados se resumieron en un informe.

Resultados. Los datos sobre la composición del personal de salud en los tres países indicaron que se depende de recursos humanos para la salud que presentan escasos niveles de educación y formación, y que la integración de las parteras tradicionales es limitada. En los tres países, el tratamiento de las urgencias obstétricas constituyó una prioridad de capacitación para las enfermeras tituladas, y la detección de los signos de peligro fue una prioridad en el caso de los agentes comunitarios de salud y las parteras tradicionales. Las prioridades de formación para las enfermeras auxiliares variaron sustancialmente entre los tres países y entrañaron la promoción de la salud, la atención pregestacional y prenatal, y las urgencias obstétricas. Asimismo, el número total de recursos humanos para la salud varió considerablemente entre los países.

Conclusiones. Depender de personal de salud de escaso nivel formativo es motivo de preocupación, si bien la capacitación en el servicio puede mitigar este problema. Las prioridades de capacitación están en consonancia con las principales causas de mortalidad materna y los programas formativos de América Latina y el Caribe resultan prometedores para mejorar la calidad de la atención. A largo plazo, la planificación de los recursos humanos para la salud dedicados a la atención materna deberá procurar aumentar la concentración de profesionales de salud más capacitados.

Recursos humanos; servicios de salud maternal; atención primaria de salud; creación de capacidad; planificación estratégica; América Latina; región del Caribe; Colombia; Honduras; Nicaragua. 
RESUMO

\section{Prioridades em formação em saúde materna para profissionais de enfermagem e outros profissionais da saúde na Colômbia, Honduras e Nicarágua}

Objetivo. Avaliar as prioridades de formação em saúde materna dos recursos humanos na área de atenção primária à saúde entre profissionais de enfermagem e outros profissionais da saúde na Colômbia, Honduras e Nicarágua, a fim de subsidiar os esforços de planejamento estratégico de recursos humanos para saúde materna.

Métodos. Foi conduzido um estudo transversal, sediado em Washington, D.C., para coletar dados ao nível nacional. Uma ferramenta de avaliação das necessidades foi desenvolvida, de outubro de 2016 a março de 2017, pela Organização Pan-Americana da Saúde/Organização Mundial da Saúde (OPAS/OMS) e Centros Colaboradores da OPAS/OMS. A coleta de dados foi concluída pelas representações da OPAS/OMS nos países, em colaboração com autoridades sanitárias nacionais e pessoal de alto escalão do governo. Foram coletados dados sobre a composição, as competências e as prioridades de formação de parteiras tradicionais, agentes comunitários de saúde, enfermeiros licenciados e assistentes de enfermagem nos três países de estudo. Os resultados foram compilados em um relatório.

Resultados. Os dados relativos à composição da força de trabalho em saúde nos três países indicaram que eles contam com pessoal com baixo nível de instrução e formação, com integração limitada das parteiras tradicionais. Observou-se, nos três países, que a atuação em emergências obstétricas era uma prioridade de formação para enfermeiros licenciados e a identificação de sinais de perigo era uma prioridade para agentes comunitários de saúde e parteiras tradicionais. As prioridades de formação para os assistentes de enfermagem foram bastante distintas entre os países: promoção da saúde, cuidados pré-concepcionais e assistência pré-natal e emergências obstétricas. O número total de recursos humanos para a saúde também variou nos três países.

Conclusões. É motivo de preocupação ter de contar com profissionais da saúde com baixo nível de formação, porém este problema pode ser reduzido com a capacitação no próprio serviço. As prioridades de formação nos países estudados são condizentes com as principais causas de mortalidade materna e os programas de formação profissional da Região da América Latina e Caribe têm potencial para melhorar a qualidade da atenção. O planejamento dos recursos humanos para saúde materna deve visar a longo prazo aumentar a concentração de profissionais que são mais capacitados.

Palavras-chave

Recursos humanos; serviços de saúde materna; atenção primária à saúde; fortalecimento institucional; planejamento estratégico; América Latina; região do Caribe; Colombia; Honduras; Nicaragua. 